\title{
EXPERIMENTAL INVESTIGATION OF AN AIR-SOURCE HEAT PUMP IN DIFFERENT REAL OPERATIONAL CONDITIONS FOR DISTINCTIVE HEATING REGIMES
}

\author{
UDC 621.57:.620.9
}

\section{Goran Vučković, Mića Vukić, Mirko Stojiljković, Marko Ignjatović}

University of Niš, Faculty of Mechanical Engineering in Niš, Niš, Serbia

\begin{abstract}
In a time of permanent care for environmental protection, energy consumption and conservation of resources, heat pumps are becoming increasingly important as a technology for reducing greenhouse gas emissions while preserving thermal comfort in the built environment. This paper presents the experimental results of an air-source heat pump in different real operating conditions, as follows: for space heating by lowtemperature underfloor heating when the supply water temperature was set to $38^{\circ} \mathrm{C}$, or for domestic hot water heating in a storage tank with the volume of 180 litres at a temperature of $46^{\circ} \mathrm{C}$. In the low-temperature underfloor heating mode, the efficiency of the air-source heat pump could be increased if the maximum temperature at the end of the compression process and the condensing temperature were reduced in the initial phase of the heat pump operation. In the domestic hot water heating mode, the efficiency of the air-source heat pump could be increased if the maximum condensation temperature in the final phase of the heat pump operation was limited.
\end{abstract}

Key words: heat pump, experimental investigation, space heating, domestic hot water.

\section{INTRODUCTION AND BACKGROUND}

One of the most promising technologies to reduce the carbon dioxide footprint is provided by heat pumps. Heat pumps use renewable energy and may be the single most efficient technology for heating and cooling, particularly when both services are required in the same location and at the same time [1].

Heat pumps offer an energy-efficient way to provide space heating and sanitary hot water preparation in the built environment. The use of air-source heat pumps is increasing to meet the energy needs of residential buildings, and manufacturers of equipment have permanently expanded the range of work and improved the coefficient of performance (COP) in very adverse outdoor air conditions (high humidity and very low temperatures).

Received September 6, 2020 / Accepted October 5, 2020

Corresponding author: Goran Vučković

University of Niš, Faculty of Mechanical Engineering, Aleksandra Medvedeva 14, 18000 Niš, Serbia

E-mail: goran.vuckovic@masfak.ni.ac.rs 
A transition to a low-carbon energy world is likely to lead to a fundamental shift in the global energy system. The building sector (residential, commercial, and public) has become the largest consumer of primary energy in the world. The heat pump technology becomes one of the most important technologies for decarbonizing heating, ventilation, air-conditioning, and cooling in the built environment. Most heat pump systems in common use today are of the vapour-compression type [2]. The R410A refrigerant fluid is frequently used in the vapour-compression type of refrigeration and air-conditioning systems due to its high energy efficiency ratio [3].

Nearly 20 million households purchased heat pumps in 2019. Although heat pumps have even become the most common technology in newly built houses in many countries, they meet only $5 \%$ of the global building heating demand, while fossil fuel-based and conventional electric technologies made up three-quarters of sales globally in 2019. The construction segment of the buildings sector is responsible for most heat pump technology purchases, and in many countries, heat pumps register the highest market share of all heating technologies. In the United States, for example, the share of heat pump sales for newly constructed buildings exceeds $40 \%$ for single-family dwellings and is nearly $50 \%$ for new multi-family buildings [4].

Air-to-air heat pumps have rapidly become widespread in recent years and now dominate global sales for buildings. In the United States, for example, annual shipments expanded from 2.3 million units in 2015 to 3.1 million in 2019 . Several factors have raised the popularity of air-to-air technologies, including policy development, upgraded construction standards that make heat pumps in new buildings more competitive, and growing air-conditioning demand.

Sales of heat pump water heaters (for sanitary hot water) have more than tripled since 2010, largely owing to purchases in China. Subsidies to replace coal-fired boilers with air-to-water heat pumps through northern China's Coal-to-Electricity programme helped raise sales to 1.3 million units in 2017. Japan is the second-largest market, although sales decreased slightly from 570,000 units in 2010 to 480,000 in 2018 [4].

With a $12 \%$ increase reached in 2018 , the European heat pump market achieved doubledigit growth for the fourth year in a row. At this rate, a doubling of the European heat pump market by 2024 is expected. Thanks to the 11.8 million units installed across Europe, heat pump technology has quickly developed into a cornerstone of Europe's heat supply. Currently, heat pumps are heating slightly less than $10 \%$ of all buildings, but there is still a vast untapped potential to be unleashed. With their thermal and demand-side flexibility potential, heat pumps will be required in the new energy system to achieve the 2050 climate targets [5].

Paper [6] presents an energy performance evaluation of a low global warming potential refrigerant, L-41b, as a replacement for R410A. The experiment was carried out in the climatic chamber, where the temperature was maintained within a range between $10^{\circ} \mathrm{C}$ and $30^{\circ} \mathrm{C}$. The condenser outlet water temperature was controlled between $25^{\circ} \mathrm{C}$ and $45^{\circ} \mathrm{C}$, followed by maintaining the water temperature difference of $5^{\circ} \mathrm{C}$ in the condenser inlet and outlet. Adopting an internal heat exchanger has the potential of lowering the differences of performance, besides approaching the L- $41 \mathrm{~b}$ performance to the one attained with the use of R410A in the existing air-source heat pump.

Paper [7] proposes an innovative hybrid energy system of a solar air collector, airsource heat pump and energy storage, which is utilized to save energy for ultra-low energy buildings in severe cold regions. The results indicate that, where the outdoor heating calculation temperature is lower than $-30^{\circ} \mathrm{C}$ and solar energy resources are not particularly abundant, the peak inlet air temperature of the air-source heat pump increases by no less 
than $10^{\circ} \mathrm{C}$ and the coefficient of performance of the system is expected to be higher than 3.0 under extremely low temperature conditions.

A multifunctional heat pump system that can be run in four modes is analyzed in [8]. COP, exergy efficiency and exergy destruction of heat pumps were evaluated, compared and discussed. The comparison was made regarding temperature and mass flow rate changes of the evaporator fluid. The results show that the best type of heat pump with the maximum COP value is the water to air type with 3.94 , followed by the water to water type with 3.73 , the air to air type with 3.54 and the air to water type with 3.40 .

Paper [9] proposes a novel cascade system combining the characteristic of a conventional air-source heat pump and a low temperature air-source heat pump with R410A as a refrigerant fluid. Variable-speed characteristics and control strategies of the two heating modes were investigated. The proposed new system has excellent low temperature characteristics. The coefficient of performance of the cascade compression heating mode first increases and then decreases along with the increase of the lower-stage compressor speed. Under a condensing temperature of $46^{\circ} \mathrm{C}$ and an evaporating temperature of $-35^{\circ} \mathrm{C}$, the COP was higher than 1.8 , the discharge temperature was lower than $120^{\circ} \mathrm{C}$, indicating that this system can function safely and steadily in cold climates.

In paper [10], the impact of indoor air conditions on the performance of an air-source heat pump water heater was established under experimental and simulation investigation. The air-source heat pump showed a net reduction of $21.3 \%$ in the electricity consumption of the house. The best coefficient of performance was obtained at $20^{\circ} \mathrm{C}$ and $35 \%$ relative humidity from the chosen sets of air conditions. The COP varies between 1.5 and 5 for the chosen set of indoor air conditions. The outlet water temperature fluctuates in the range of $49.5^{\circ} \mathrm{C}$ to $55.9^{\circ} \mathrm{C}$ (while the setpoint temperature was taken at $54^{\circ} \mathrm{C}$ ).

In paper [11], an innovative clean air heat pump was designed, developed, and investigated. Experimental studies were conducted to investigate the energy performance of the clean air heat pump under different outdoor climates. The clean air heat pump is more energy-efficient than a conventional air source heat pump (could save up to 5\%, $13 \%$ of electricity for ventilation and heating in the winter period of Copenhagen and Milan, respectively). The energy consumption of the clean air heat pump is sensitive to the outdoor air humidity ratio.

In paper [12], an air-to-air heat pump and air-to-water heat pump heating system were tested in an environmental laboratory. The COP degradation of the air-to-water heat pump was more severe than that of the air-to-air heat pump in cold conditions. The air-toair heat pump had a higher average indoor temperature and better thermal comfort than the air-to-water heat pump. The decrease in the actual COP operation of the air-to-air heat pump was $28.30 \%$, which was smaller than that of the air-to-water heat pump by $15.45 \%$ with the ambient temperature decreasing from $7^{\circ} \mathrm{C}$ to $-20^{\circ} \mathrm{C}$.

This paper presents the experimental results of an air-source heat pump in two different real operational modes: the low-temperature mode for space heating through the underfloor heating system and the high-temperature mode for domestic hot water preparation. The paper points out the possibilities for improving the efficiency of the heat pump for both considered operating modes. 


\section{EXPERIMENTAL INVESTIGATION OF THE AIR-SOURCE HEAT PUMP}

A schematic of a vapour compression air-source heat pump water heater is shown in fig. 1. The air-source vapour-compression heat pump is constructed as a split-system with the following main components: vapour compressor $(\mathrm{CM})$, evaporator $(\mathrm{EV})$ with a fan (FA), four-way/reversing valve (RV) and throttling valve (TV), heat exchanger/condenser (CD), three-way/diversion valve (DV), circulating pump (CP), and domestic hot water (DHW) pre-insulated accumulation tank with the volume of 180 litres.

The heat pump operates in the heating mode in accordance with the reversing valve position, fig. 1. In the inverter drive vapour compressor, slightly overheated low-pressure vapour (state 1) is compressed to a higher pressure and temperature, which is registered with digital sensors. Superheated high-pressure vapour (state 2) enters the condenser where it is cooled, condensed and subcooled (state 3). The temperature is measured at this point. Reducing the liquid pressure is done in the TV (process 3-4). The cold liquid-vapor mixture (state 4) enters the EV where it evaporates by cooling the air and is slightly overheated (state 1). The evaporation temperature is measured with a surface mounted temperature sensor. Heat transfer in the EV is intensified by the continuous operation of an inverter-driven fan. The cooled air leaves the evaporator in state 12 .

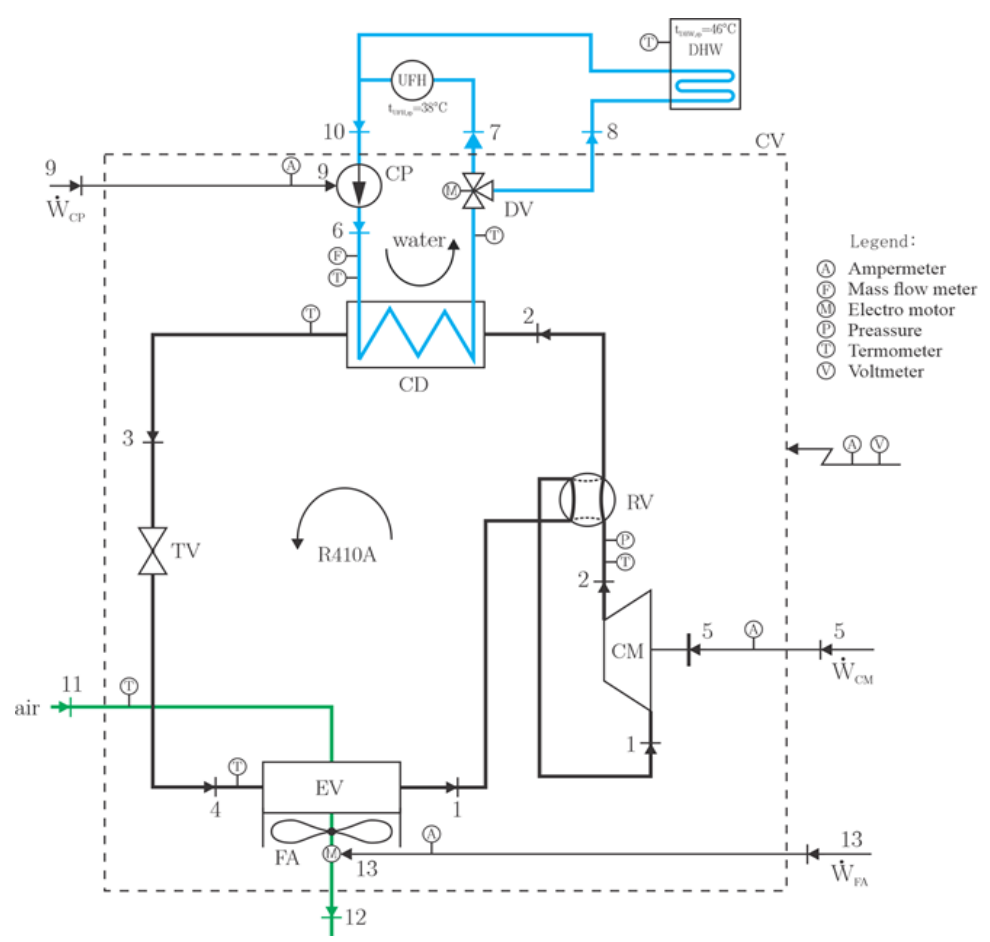

Fig. 1 Flow diagram of an air-source heat pump with positions of measuring equipment

Circulating water from the secondary circuit is used as a heat sink. The condenser is constructed as an insulated counterflow plate heat exchanger. Circulating water flow and temperature (state 6) are measured at the condenser inlet and additionally leaving water 
temperature is measured at the condenser outlet (state 7(8)). The circulating pump is also driven by an inverter.

The supply of electricity to the compressor, fan and circulating pump is managed through a $230 \mathrm{~V}$ power supply from the public company and represented with flows 5, 9 and 13. For all components, the electricity is measured with ampermeters, fig. 1.

For the purpose of this research, two different heating energy consumers are analysed: space heating via low temperature $\left(\mathrm{t}_{7}=\mathrm{t}_{\mathrm{UFH}, \mathrm{sp}}=38^{\circ} \mathrm{C}\right)$ underfloor heating (UFH) and domestic hot water preparation in an accumulation tank at higher temperature levels $\left(\mathrm{t}_{\mathrm{DHW}} \mathrm{sp}\right.$ $=46^{\circ} \mathrm{C}$ ). Heating energy supply changeover is done with an electrically actuated threeway/diversion valve, fig. 1 . When the diversion valve is in the position for space heating cycle 7-10-6 is enabled, while when it is in the position for DHW preparation, cycle 8-10-6 is running, fig. 1. In total, 13 spot measurements are performed ( 7 for temperature, 4 for electricity, 1 for water flow and 1 for water pressure). The heat pump was used for space heating in the period from 00:14:50 to 02:09:40 (30-01-2020), during which 690 readings were recorded for every measuring spot, resulting in a total of 8970 readings. During this operation, the control parameter was the supply water temperature with a setpoint of $38^{\circ} \mathrm{C}$. The setpoint was reached in 8 minutes and 30 seconds, and after this point, the air-source heat pump was in the modulating regime, i.e. the $\mathrm{CM}$ and the $\mathrm{CP}$ were adjusted to real demand. Since starting with the modulating regime, the heat pump (setpoint was) reached (full control) after 55 minutes and 20 seconds, fig. 2. The DHW preparation run was conducted in the period from 22:15:20 to 22:48:00 (29-01-2020), during which 197 readings were recorded per measuring spot, resulting in a total of 2561 readings. In this case, the control parameter was the tank water temperature with a setpoint of $46^{\circ} \mathrm{C}$. The setpoint was reached in 36 minutes and 40 seconds, resulting in the unit being switched off, fig. 3. The heat pump operation was monitored, and the parameters were recorded with the measuring equipment supplied by the manufacturer.

The maximum coefficient of performance is reached when heat pumps operate in the ideal Carnot cycle with reversible processes. In that case, the efficiency is dependent only on the heat source temperature (evaporation temperature) and the heat sink temperature (condensing temperature) [13]:

$$
{ }^{\mathrm{COP}} \mathrm{C}=\frac{\mathrm{T}_{\text {con }}}{\mathrm{T}_{\text {con }}-\mathrm{T}_{\text {evp }}}
$$

The real thermodynamic cycles have a lower efficiency than the Carnot cycle. The Coefficient of performance (energy-based efficiency measure) of the overall air-source heat pump in this paper can be defined as follows:

$$
\mathrm{COP}_{\text {tot }}=\frac{\dot{\mathrm{Q}}_{\mathrm{EU}}}{\dot{\mathrm{W}}_{\text {tot }}} ; \quad\left(\mathrm{COP}_{\text {tot }}<\mathrm{COP}_{\mathrm{C}}\right)
$$

The dividend in equation (2) represents the heat delivered to the end-user. In the first case, it is the heat delivered to the space heating system via underfloor heating $\left(\dot{\mathrm{Q}}_{\mathrm{EU}}=\dot{\mathrm{Q}}_{\mathrm{UFH}}=\dot{\mathrm{m}}_{\mathrm{W}}\left(\mathrm{h}_{7}-\mathrm{h}_{10}\right)\right.$. In the other case, it is the heat delivered to the water in the tank for domestic hot water preparation $\left(\dot{\mathrm{Q}}_{\mathrm{EU}}=\dot{\mathrm{Q}}_{\mathrm{DHW}}=\dot{\mathrm{m}}_{\mathrm{W}}\left(\mathrm{h}_{8}-\mathrm{h}_{10}\right)\right.$ ).

Measurements in the selected points of the described processes (fig. 1) were used for calculating thermodynamic variables. For every parameter, basic statistics were applied 
and the average value, median and standard deviation were calculated based on the following expressions, respectively [14]:

$$
\begin{aligned}
& \overline{\mathrm{X}}=\frac{1}{\mathrm{~N}} \sum_{\mathrm{i}=1}^{\mathrm{N}} \mathrm{X}_{\mathrm{i}} \\
& \mu_{X}=\left\{\begin{array}{c}
X_{i} \text {, where is } i=(N+1) / 2 \text { and } N \text { odd number } \\
\frac{X_{i}+X_{i+1}}{2}, \text { where is } i=N / 2 \text { and } N \text { even number }
\end{array}\right. \\
& \sigma_{X}=\left|\sqrt{\frac{1}{N} \sum_{i=1}^{N}\left(X_{i}-\bar{X}\right)^{2}}\right|
\end{aligned}
$$

\section{RESULTS AND DISCUSSIONS}

The results presented in this paper are related to a low-temperature air-source heat pump with variable speed compressor operation technology (inverter technology). The nominal heating capacity of the outdoor unit is $6.0 \mathrm{~kW}$ (model ERLQ006CV3) and the indoor unit has an integrated hydro-module and a DHW water tank of 180 litres (model EHVX08S18CB3V) [15].

A comparison of the air-source heat pump performance in real operating conditions is done for two distinctive regimes. The essential difference between these two modes of operation lies in the set ultimate goals. In the case of operation in the space heating mode via low-temperature underfloor heating, the goal is first to reach and then maintain the temperature of the supply water, $\mathrm{t}_{7}=\mathrm{t}_{\mathrm{UHF}, \mathrm{sp}}=38^{\circ} \mathrm{C}$. On the other hand, in the case of operation in the mode of heating sanitary hot water, the goal is only to heat the water in the accumulation tank to the set point temperature, $t_{\mathrm{DHW}, \mathrm{sp}}=46^{\circ} \mathrm{C}$. In that sense, the operation of the heat pump is adjusted to the set requirements and is different in both cases. Since it is a heat pump with air as a source of heat energy, the evaporation temperature of the refrigerant is conditioned by the parameters of the ambient air, primarily by the air temperature. When the heat pump operates in the heating mode, the heat necessary for the process of evaporation of the refrigerant is removed from the ambient air, and in that sense, the temperature of evaporation of the refrigerant must be lower than the ambient temperature by $3 \div 5^{\circ} \mathrm{C}$. It should be noted that in order to achieve the high efficiency of the heat pump (eq. (1)), it is desirable that the evaporation temperature of the refrigerant be as close as possible to the temperature of the heat source.

During the UHF operation, fig. 2., the objective was to reach the space heating system supply water temperature of $38^{\circ} \mathrm{C}\left(\mathrm{t}_{7}=\mathrm{t}_{\mathrm{UFH}, \mathrm{sp}}=38^{\circ} \mathrm{C}\right)$. During start-up, this temperature was $35.7^{\circ} \mathrm{C}$. The heat pump compressor started at full capacity leading to a permanent temperature rise of vapor at the compressor outlet from $54.5^{\circ} \mathrm{C}$ to a maximum of $93.0^{\circ} \mathrm{C}$. Condensing temperature was increased in this period from $38.1^{\circ} \mathrm{C}$ to a maximum of $44.6^{\circ} \mathrm{C}$. Fig. 2 shows that temperatures $t_{2}, t_{\text {con }}$ and $t_{7}$ have similar/same trends, only the oscillations are different. The temperature $t_{2}$ has the largest oscillations, while the temperature $t_{7}$ oscillates the least around the set temperature $t_{7, s p}=38^{\circ} \mathrm{C}$. Supply water temperature was reached in $8.5 \mathrm{~min}$. The setpoint was exceeded due to the system's inertia, and this triggered the modulating operation of 
the heat pump, i.e. the compressor power supply was changed according to the actual heat demand. The essence of inverter technology [15] was confirmed by the movement of the feedwater temperature during the experiment.

The modulating operation led to a decrease in the heat capacity (at first, vapour temperature at the compressor outlet was steadily decreasing, leading to a condensing temperature decrease, and later to a further decrease in temperature variations), and after $55.5 \mathrm{~min}$, the heat pump reached full control, with temperature set-point deviations smaller than $\pm 0.4^{\circ} \mathrm{C}$, i.e. $\leq 1.0 \%$. Vapour temperature at the compressor outlet was steadily around $60^{\circ} \mathrm{C}$. Heat source temperature $\left(\mathrm{t}_{11}\right)$ during the same time was in the range from $5.0^{\circ} \mathrm{C}$ to $-0.5^{\circ} \mathrm{C}$ and it was followed by evaporating temperature and, since from eq. (1) it is desirable to have a smaller difference between condensing and evaporating temperature, which led to the heat pump performance increase $\left(\Delta \mathrm{t}_{\text {lift }} \downarrow \Rightarrow \mathrm{COP}_{\mathrm{C}} \uparrow\right)$.

During the DHW preparation, fig. 3., the objective was to reach DHW tank temperature $t_{D H W, s p}=46^{\circ} \mathrm{C}$, and during this operation, the tank was treated as the end-user. At the beginning of the operation, DHW tank temperature was $34.2^{\circ} \mathrm{C}$ (this value can be treated as the "ghost" value due to the sensor position and stationary conditions), and immediately after the start, it dropped to $29.9^{\circ} \mathrm{C}$ after $7 \mathrm{~min}$ of operation (this temperature represents the actual, real temperature for the analysis). The heat pump compressor started at full capacity leading to a permanent temperature rise of vapour at the compressor outlet from $64.5^{\circ} \mathrm{C}$ to a maximum of $96.5^{\circ} \mathrm{C}$, and after a certain time, this temperature was steadily around $90^{\circ} \mathrm{C}$. Condensing temperature increased from $37.0^{\circ} \mathrm{C}$ to a maximum of $56.9^{\circ} \mathrm{C}$.

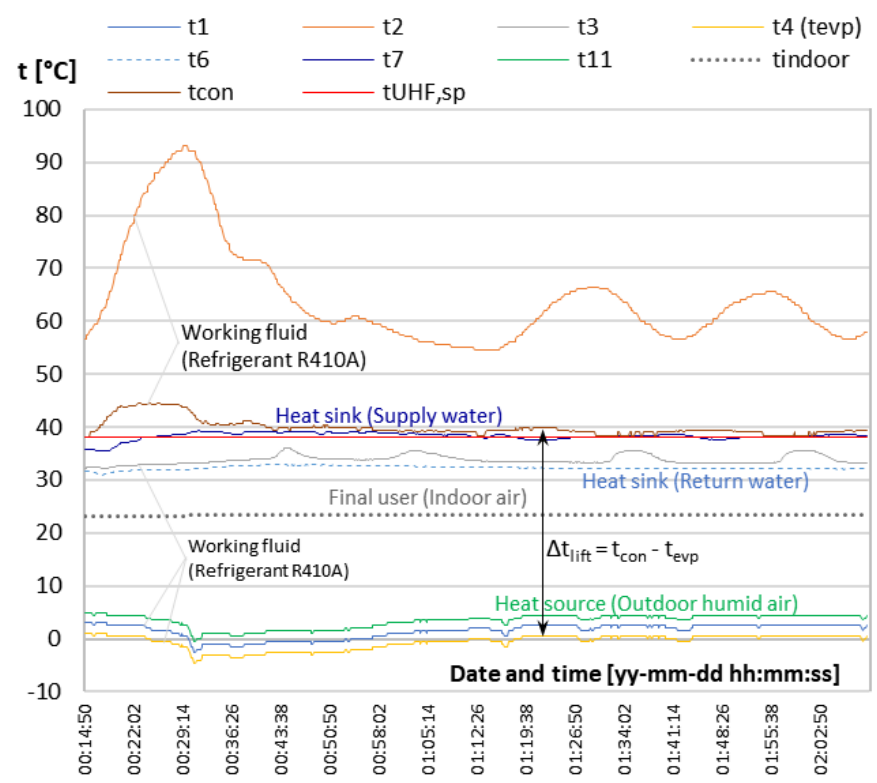

Fig. 2 Temperature profiles of process fluids during the low-temperature UFH 


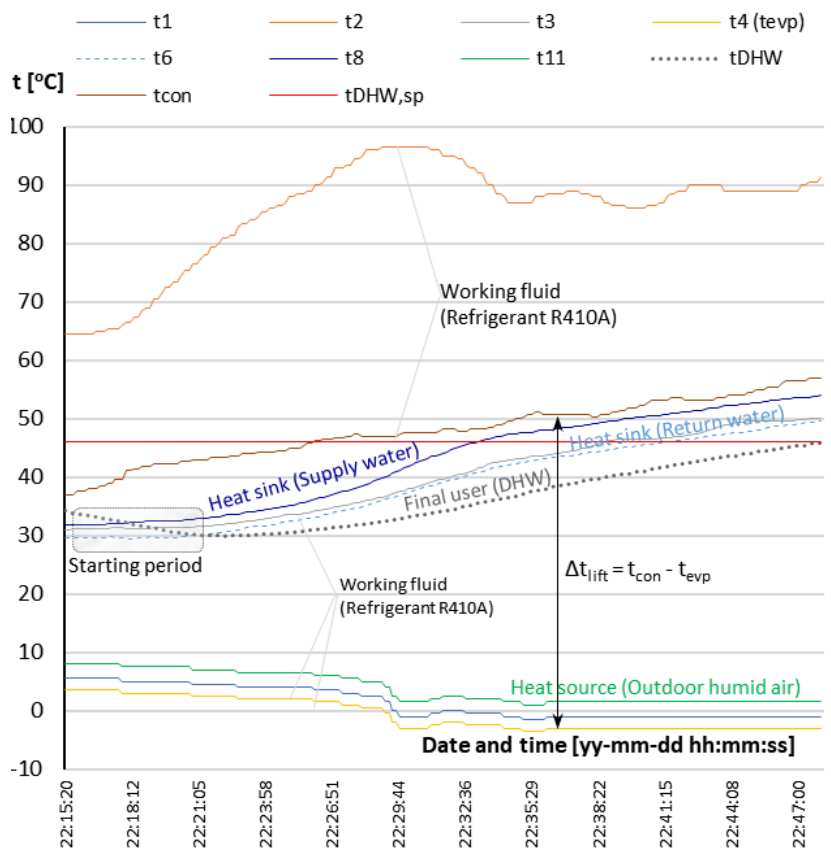

Fig. 3 Temperature profiles of process fluids during the domestic hot water heating

During the same period, the heat source (outdoor air) temperature $\left(t_{11}\right)$ was between $1.0^{\circ} \mathrm{C}$ and $8.0^{\circ} \mathrm{C}$, and it was followed by evaporating temperature. Unlike the UHF operation, in this situation, the heat pump did not enter the modulating operation since it shut down after reaching the setpoint value. Statistical analysis of the measurement reveals that for both types of operation enough data was obtained and that average values could be used for further analysis. Besides these statistical values, tab. 1. gives the overview of values of the most important thermodynamic parameters of the system, for both regimes.

Figure 4 shows three characteristic thermodynamic cycles of the refrigerant R410A (max., min., and medium) of the air-source heat pump in the space heating mode via lowtemperature UFH. During the implementation of experimental measurements, the temperature of the heat source (outdoor air) ranged from $-0.50 \div 5.00^{\circ} \mathrm{C}$ (tab. 1, fig. 2), and accordingly, the evaporation temperature of the refrigerant ranged from $-4.50 \div 1.00^{\circ} \mathrm{C}$, tab. 1, fig. 2 and fig. 4. The maximum thermodynamic cycle of the refrigerant (red cycle), fig. 4 , is a consequence of the tendency of the heat pump to reach the set temperature of the supply water of $38.0^{\circ} \mathrm{C}$ as soon as possible, which was $35.7^{\circ} \mathrm{C}$ at the time of switching on the heat pump. At the maximum thermodynamic cycle, a significant increase in the temperature of superheated refrigerant vapor at the outlet of the compressor was observed (state $2, \mathrm{t}_{2, \max }=$ $93.0^{\circ} \mathrm{C}$ ). This mode was achieved in the initial phase of the heat pump operation (14 minutes and 30 seconds after starting) and lasted relatively shortly (30 seconds), fig. 2, after which the superheated steam temperature dropped for a long time (45 minutes and 40 seconds). Before the end of the operation, the temperature of the refrigerant at the outlet of the compressor did not exceed $66.5^{\circ} \mathrm{C}$. 
Table 1 Statistical values of selected thermodynamic parameters for the overall system

\begin{tabular}{|c|c|c|c|c|c|c|c|c|c|c|c|}
\hline \multirow{2}{*}{$\begin{array}{l}\text { Para- } \\
\text { meters }\end{array}$} & \multirow{2}{*}{ Unit } & \multicolumn{5}{|c|}{ Low temperature underfloor heating } & \multicolumn{5}{|c|}{ Domestic hot water heating } \\
\hline & & Average & Median & St.dev. & Max. & Min. & Average & Median & St.dev. & Max. & Min. \\
\hline $\mathrm{t}_{1}$ & {$\left[{ }^{\circ} \mathrm{C}\right]$} & 1.41 & 2.00 & 1.33 & 3.00 & -2.50 & 1.34 & -0.50 & 2.66 & 5.50 & -1.50 \\
\hline $\mathrm{p}_{1}$ & [bar] & 7.84 & 7.98 & 0.33 & 8.24 & 6.90 & 7.84 & 7.36 & 0.67 & 8.91 & 7.13 \\
\hline $\mathrm{h}_{1}$ & {$[\mathrm{~kJ} / \mathrm{kg}]$} & 423.43 & 423.62 & 0.44 & 423.94 & 422.12 & 423.39 & 422.80 & 0.85 & 424.70 & 422.46 \\
\hline $\mathrm{s}_{1}$ & {$[\mathrm{~kJ} / \mathrm{kgK}]$} & 1.820 & 1.819 & 0.003 & 1.827 & 1.817 & 1.820 & 1.824 & 0.005 & 1.825 & 1.812 \\
\hline $\mathrm{t}_{2}$ & {$\left[{ }^{\circ} \mathrm{C}\right]$} & 64.43 & 61.25 & 9.65 & 93.00 & 54.50 & 85.62 & 88.50 & 8.98 & 96.50 & 64.50 \\
\hline $\mathrm{p}_{2}$ & [bar] & 22.62 & 22.30 & 1.07 & 26.00 & 21.50 & 28.74 & 28.90 & 3.82 & 34.80 & 20.90 \\
\hline $\mathrm{h}_{2}$ & {$[\mathrm{~kJ} / \mathrm{kg}]$} & 463.63 & 460.18 & 10.31 & 493.59 & 452.37 & 480.40 & 479.88 & 7.90 & 494.07 & 465.12 \\
\hline $\mathrm{S}_{2}$ & {$[\mathrm{~kJ} / \mathrm{kgK}]$} & 1.852 & 1.843 & 0.027 & 1.933 & 1.818 & 1.880 & 1.873 & 0.021 & 1.918 & 1.851 \\
\hline$t_{\text {con }}$ & {$\left[{ }^{\circ} \mathrm{C}\right]$} & 39.91 & 39.50 & 1.56 & 44.60 & 38.10 & 47.98 & 47.90 & 5.07 & 56.90 & 37.00 \\
\hline $\mathrm{p}_{\mathrm{con}}$ & [bar] & 22.62 & 22.30 & 1.07 & 26.00 & 21.50 & 28.74 & 28.90 & 3.82 & 34.80 & 20.90 \\
\hline$t_{3}$ & {$\left[{ }^{\circ} \mathrm{C}\right]$} & 33.30 & 33.50 & 0.83 & 36.00 & 32.10 & 39.77 & 39.70 & 6.83 & 50.10 & 31.00 \\
\hline $\mathrm{p}_{3}$ & [bar] & 22.62 & 22.30 & 1.07 & 26.00 & 21.50 & 28.74 & 28.90 & 3.82 & 34.80 & 20.90 \\
\hline $\mathrm{h}_{3}$ & {$[\mathrm{~kJ} / \mathrm{kg}]$} & 253.98 & 254.38 & 1.55 & 258.96 & 251.92 & 265.68 & 265.13 & 12.59 & 285.07 & 250.01 \\
\hline $\mathrm{S}_{3}$ & {$[\mathrm{~kJ} / \mathrm{kgK}]$} & 1.185 & 1.183 & 0.005 & 1.198 & 1.175 & 1.217 & 1.216 & 0.039 & 1.276 & 1.169 \\
\hline $\mathrm{t}_{4}\left(\mathrm{t}_{\mathrm{evp}}\right)$ & {$\left[{ }^{\circ} \mathrm{C}\right]$} & -0.59 & 0.00 & 1.33 & 1.00 & -4.50 & -0.66 & -2.50 & 2.66 & 3.50 & -3.50 \\
\hline $\mathrm{p}_{4}$ & [bar] & 7.84 & 7.98 & 0.33 & 8.24 & 6.90 & 7.84 & 7.36 & 0.67 & 8.91 & 7.13 \\
\hline $\mathrm{h}_{4}$ & {$[\mathrm{~kJ} / \mathrm{kg}]$} & 254.91 & 254.38 & 1.55 & 258.96 & 251.92 & 265.68 & 265.13 & 12.59 & 285.07 & 250.01 \\
\hline $\mathrm{S}_{4}$ & {$[\mathrm{~kJ} / \mathrm{kgK}]$} & 1.202 & 1.200 & 0.006 & 1.218 & 1.189 & 1.242 & 1.240 & 0.049 & 1.315 & 1.181 \\
\hline $\mathrm{t}_{7}\left(\mathrm{t}_{8}\right)$ & {$\left[{ }^{\circ} \mathrm{C}\right]$} & 38.31 & 38.40 & 0.72 & 39.30 & 35.40 & 42.68 & 44.10 & 7.88 & 54.00 & 31.80 \\
\hline $\mathrm{t}_{11}$ & {$\left[{ }^{\circ} \mathrm{C}\right]$} & 3.41 & 4.00 & 1.33 & 5.00 & -0.50 & 3.84 & 2.00 & 2.66 & 8.00 & 1.00 \\
\hline$\Delta \mathrm{t}_{\text {lift }}$ & {$\left[{ }^{\circ} \mathrm{C}\right]$} & 38.86 & 38.50 & 1.68 & 44.60 & 36.80 & 45.33 & 46.20 & 5.00 & 53.90 & 33.50 \\
\hline $\mathrm{COP}$ & {$[-]$} & 3.77 & 3.75 & 0.36 & 4.80 & 3.02 & 3.51 & 3.32 & 0.48 & 4.71 & 3.01 \\
\hline $\mathrm{COP}_{\mathrm{C}}$ & {$[-]$} & 7.75 & 7.90 & 0.39 & 8.39 & 6.74 & 6.76 & 6.34 & 1.03 & 9.25 & 5.51 \\
\hline
\end{tabular}

The rapid achievement of the set temperature of the supply water is predominantly conditioned by the criterion of comfort, but not by the criterion of efficiency. On the other hand, since in the space heating mode via low-temperature UFH the task is to maintain the supply water temperature at $38.0^{\circ} \mathrm{C}$, in order to achieve maximum efficiency, compressor technology with variable speed tends to bring the condensing temperature of the refrigerant as close as possible to the set supply water temperature. During the implementation of experimental measurements, the condensation temperature of the refrigerant ranged from $38.10 \div 44.60^{\circ} \mathrm{C}$, tab. 1 , fig. 2 and fig. 4 . Also, in addition to the effect of energy efficiency $\left(\mathrm{COP}_{\max }=4.80\right)$, the minimum deviation from the set temperature of the supply water contributes to reaching the maximum thermal comfort. Since the condensing temperature in the maximum cycle is $44.60^{\circ} \mathrm{C}$, the inverter technology of compressor operation reduces the number of compressor revolutions and changes the thermodynamic cycle. The minimum thermodynamic cycle of the refrigerant (purple cycle) is a consequence of adjusting the operation of the heat pump to maintain the temperature of the supply water at $38^{\circ} \mathrm{C}$.

Figure 4 shows that states 2 and 3 of the averaged thermodynamic cycle (blue cycle) are closer to the values of the minimum cycle, whereas states 1 and 4 are closer to the values of the maximum thermodynamic cycle, which is a direct consequence of the frequency (grouping) of measured quantities. Out of a total of 690 measurements, for state 2 the measured values of temperatures were lower than the mean values in 441 measurements $(63.9 \%)$, and higher than the mean values in 249 measurements $(36.1 \%)$, with a relative deviation of $5.58 \%$ and $15.16 \%$, respectively. 


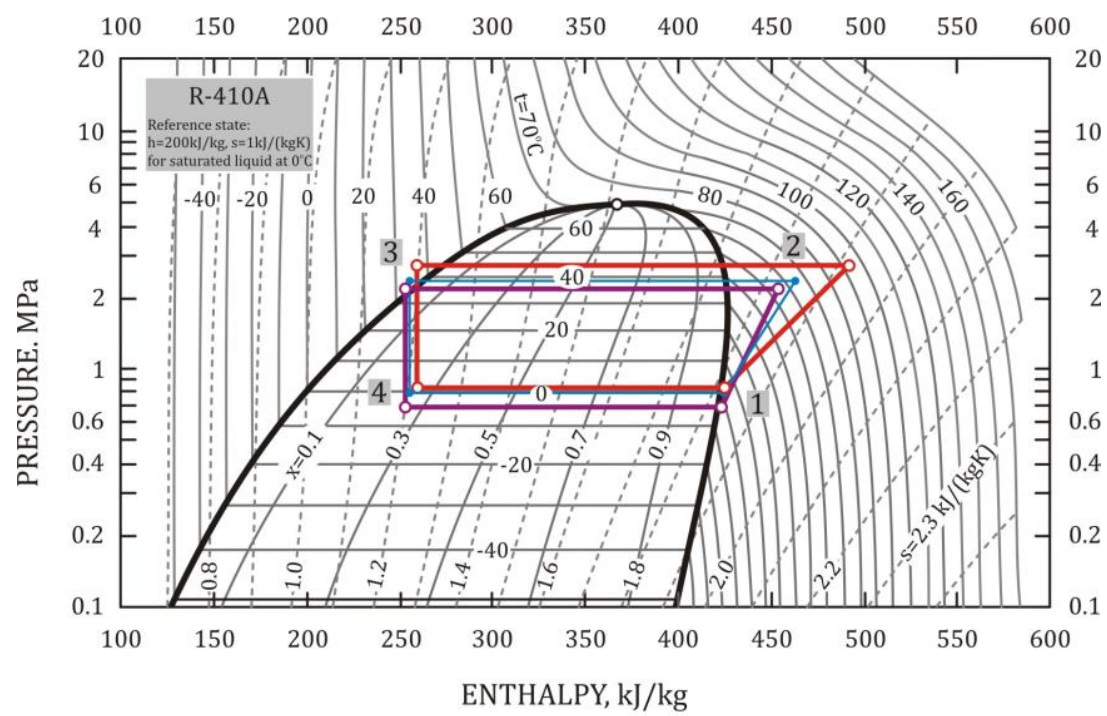

Fig. 4 Thermodynamic cycles of the refrigerant for the max., min., and an average value of temperature at the outlet of the compressor in the mode of low-temperature UFH

On the other hand, out of the total number of measurements, for state 4 , in 470 measurements $(68.11 \%)$ the registered values of measured temperatures were higher than the mean values, and in 220 measurements $(31.89 \%)$ lower than the mean values. The same conclusions are indicated by the statistical values of the median and standard deviation, tab. $1\left(\mu_{12}=61.25^{\circ} \mathrm{C}<\overline{\mathrm{t}}_{2}, \sigma_{\mathrm{t} 2}=9.65^{\circ} \mathrm{C} ; \mu_{\mathrm{t} 4}=0^{\circ} \mathrm{C}>\overline{\mathrm{t}}_{4}, \sigma_{\mathrm{t} 4}=1.33^{\circ} \mathrm{C}\right)$.

Figure 5 shows the three thermodynamic cycles of the refrigerant (max., min., and average) of the air-source heat pump in the DHW mode. During the implementation of experimental measurements, the temperature of the heat source (outdoor air) ranged from $1.00 \div 8.00^{\circ} \mathrm{C}$ (tab. 1 , fig. 3 ), and accordingly, the evaporation temperature of the refrigerant ranged from $-3.50 \div 3.50^{\circ} \mathrm{C}$, tab. 1 , fig. 3 and fig. 5 . The maximum thermodynamic cycle of the refrigerant (red cycle), fig. 5, is a consequence of the tendency of the heat pump to heat the water in the storage tank to the set temperature of $46^{\circ} \mathrm{C}$, which was $34.2^{\circ} \mathrm{C}$ at the time of switching on the heat pump, fig. 3 . The rapid achievement of the set temperature of sanitary hot water is predominantly conditioned by the criterion of comfort, but not by the criterion of efficiency. At the maximum thermodynamic cycle, an increase in the condensing temperature of the refrigerant is observed $\left(\mathrm{t}_{\mathrm{cond}, \max }=56.90^{\circ} \mathrm{C}\right.$, tab. 1 , fig. 3 and fig. 5 ). The maximum condensation temperature was reached near the end of the domestic hot water heating process, fig. 3 . Then the maximum difference between condensation and evaporation temperatures $\left(\Delta \mathrm{t}_{\text {lift,max }}=53.90^{\circ} \mathrm{C}\right)$ was achieved, which was manifested by the low energy efficiency of the heat pump $\left(\mathrm{COP}_{\mathrm{C}, \min }=5.51, \mathrm{COP}_{\min }=3.01\right)$, tab. 2. For this mode of operation, it is characteristic that the condensation temperature increased permanently during the experiment, fig. 3 , i.e. that the minimum condensation temperature was reached at the beginning $\left(\mathrm{t}_{\mathrm{cond}, \min }=37.00^{\circ} \mathrm{C}\right.$, tab 1 , fig. 3$)$, and the maximum at the end. 


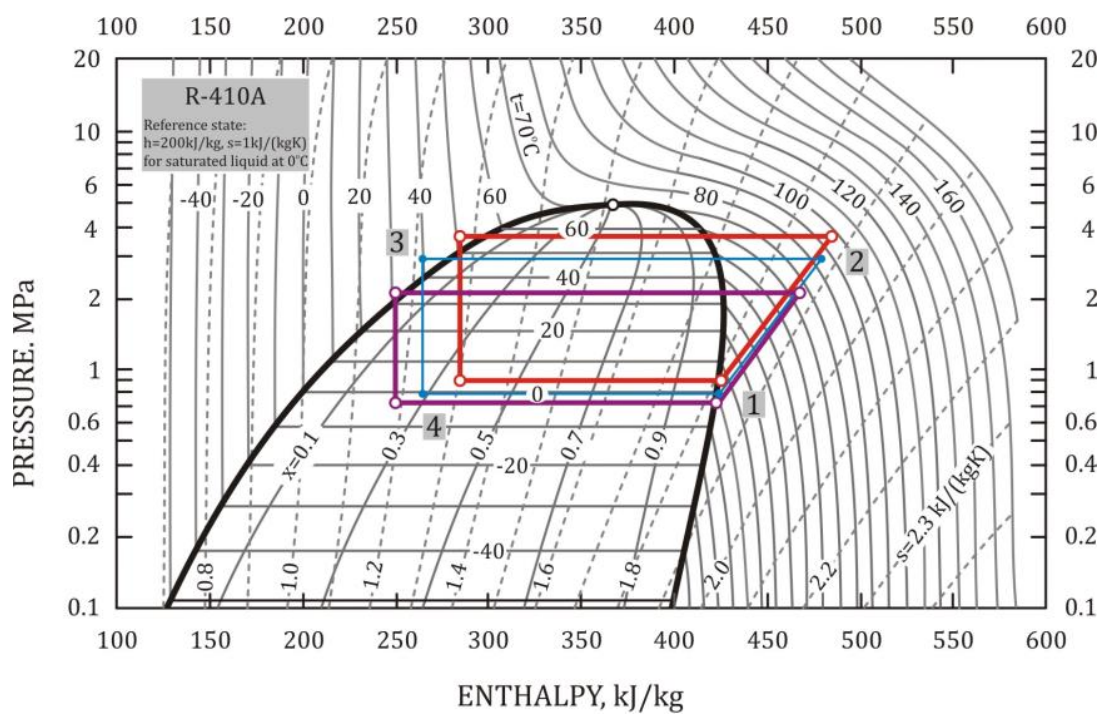

Fig. 5 Thermodynamic cycles of the refrigerant for the max., min., and medium value of temperature at the outlet of the compressor in the domestic hot water heating mode

Accordingly, the min. thermodynamic cycle (purple cycle) corresponds to the initial phase of the heat pump operation. The inverter control of compressor operation was activated after reaching the maximum temperature of superheated refrigerant steam at the end of the compression process (state $2, \mathrm{t}_{2, \max }=96.50^{\circ} \mathrm{C}$ ), but this temperature remained relatively high until the end of the operation, tab. 1 , fig. $3\left(\mu_{\mathrm{t} 2}=88.50^{\circ} \mathrm{C}, \overline{\mathrm{t}}_{2}=85.62^{\circ} \mathrm{C}\right)$.

Fig. 5 shows that states 2 and 3 of the averaged thermodynamic cycle (blue cycle) are closer to the values of the maximum cycle, and states 1 and 4 are closer to the values of the minimum thermodynamic cycle, which is, in this case, a direct consequence of the frequency (grouping) of measured quantities. Out of a total of 197 measurements, for state 2, in 53 measurements (26.9\%) the measured values of temperatures were lower than the mean value, and in 144 measurements $(73.1 \%)$ they were higher than the mean value, with the relative deviation of $14.77 \%$ and $5.43 \%$, respectively. On the other hand, out of the total number of measurements, for state 4, in 85 measurements $(43.15 \%)$ the registered values of measured temperatures were higher than the mean values, and in 112 measurements $(56.85 \%)$ lower than the mean values. The conclusions are indicated by the statistical values of the median and standard deviation, tab. $1\left(\mu_{12}=88.50^{\circ} \mathrm{C}>\overline{\mathrm{t}}_{2}, \sigma_{\mathrm{t} 2}=8.98^{\circ} \mathrm{C} ; \mu_{\mathrm{t} 4}=-2.50^{\circ} \mathrm{C}<\overline{\mathrm{t}}_{4}, \sigma_{\mathrm{t} 4}=2.66^{\circ} \mathrm{C}\right)$.

Figure 6 shows comparative diagrams with zones within which all thermodynamic cycles of the refrigerant are located during the operation of the air-source heat pump in the space heating mode via low-temperature UFH, fig. 6a, and in the DHW heating mode, fig. 6b. A much narrower zone of movement of thermodynamic cycles is observed in the case of low-temperature UFH, especially in the part of condensation and expansion of the refrigerant. In principle, the heat pump achieves higher efficiency if the difference between the condensing temperature and the evaporation of the refrigerant is as small as possible and if the zones of movement of the cycle are narrow. 


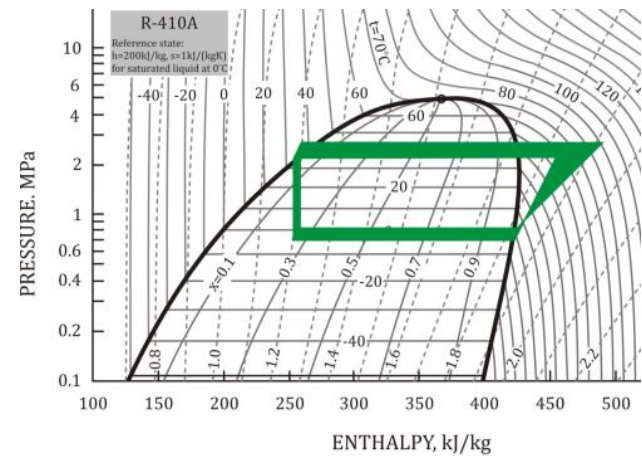

a) Low temperature underfloor heating

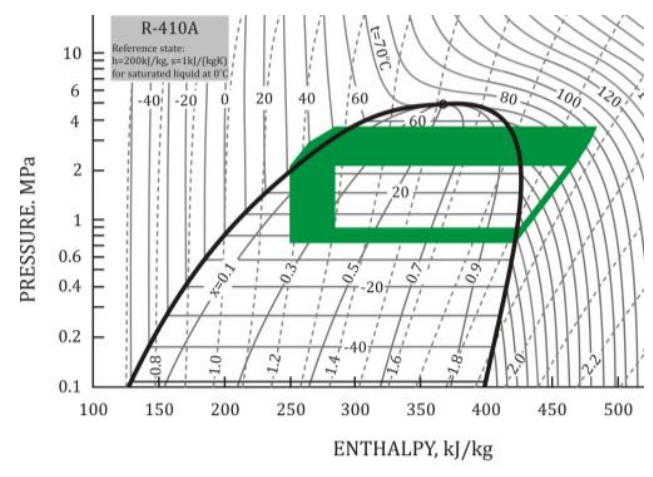

b) Domestic hot water heating

Fig. 6 Movement zones of refrigerant cycles for different heat pump operating modes

In the low-temperature UFH mode, fig. 6a, the efficiency of the air-source heat pump could be increased if the maximum temperature at the end of the compression process (state 2) and the condensing temperature were reduced in the initial phase of the heat pump operation (first 15 minutes of operation). In this way, the widths of the zones in the part of compression, cooling, condensation and subcooling of the refrigerant would be reduced, which would increase the coefficient of isentropic efficiency of the compression process, and the difference between condensation and evaporation temperature $\left(\Delta t_{\text {lift }}\right)$ would be reduced, which has direct positive effects on the increase in COP. In the lowtemperature UFH mode, the same efficiency, but better environmental performance would be achieved if the refrigerant $\mathrm{R} 410 \mathrm{~A}$ were replaced by $\mathrm{L}-41 \mathrm{~b}$, according to the recommendations from reference [6].

In the DHW heating mode, fig. $6 \mathrm{~b}$, the efficiency of the heat pump could be increased if the maximum condensing temperature in the final phase of the heat pump operation was limited (last 6 minutes of operation, fig. 3). In this way, the widths of the zones in the part of cooling, condensation, subcooling and expansion of the refrigerant would be reduced, i.e. the difference between the condensing and evaporating temperature $\left(\Delta t_{\text {lift }}\right)$ would be reduced and the energy efficiency of the heat pump would increase. Also, in the DHW mode increase of efficiency can be achieved by using a hybrid energy system with a solar air collector, in accordance with reference [7].

Since it is necessary to use electricity to drive the compressor to operate the vaporcompression heat pump, increasing the energy efficiency of the heat pump has direct positive consequences on reducing greenhouse gas emissions and protecting the environment, because in that case most of the energy is used from ambient air, with a smaller portion used from the public electricity network. From the energy point of view, the low-temperature underfloor heating regime of the air-source heat pump for space heating is $6.9 \%$ more efficient, compared to the domestic hot water regime, tab. 1. 


\section{CONCLUSIONS}

From the energy analysis point of view, the air-source heat pump operates with a satisfying performance for both operating regimes $(3.77 ; 3.51$; tab. 1$)$. These results show that the air-source heat pump as described is over-dimensioned for the UHF operation, but it has enough capacity for the DHW operation.

The evaporation temperature and the condensing temperature of the refrigerant have a dominant influence on the efficiency of the air-source heat pump. It is desirable that their deviation $\left(\Delta \mathrm{t}_{\text {lift }}\right)$ be as small as possible. Since the temperature of the supply water depends on the user's requirements, there is a possibility of influencing the condensing temperature, which is good. However, a generally unfavourable circumstance for heat pumps with air as the heat source is the limited controlled influence on the evaporation temperature of the refrigerant, bearing in mind that it directly depends on the atmospheric conditions (outdoor air parameters). During the experimental measurements for the purposes of this study, in the mode of operation of the air-source heat pump for the needs of space heating by low-temperature UFH, the working conditions were more favourable for the condensing temperature $\left(\mathrm{t}_{\text {con,max }}=44.6^{\circ} \mathrm{C}, \mathrm{t}_{\text {con,min }}=38.10^{\circ} \mathrm{C}, \overline{\mathrm{t}}_{\mathrm{con}}=39.91{ }^{\circ} \mathrm{C}\right)$ since the requirement for the supply water temperature was $38^{\circ} \mathrm{C}$, and less favourable for the evaporation temperature $\left(\mathrm{t}_{\mathrm{evp}, \max }=1.00^{\circ} \mathrm{C}, \mathrm{t}_{\mathrm{evp} \text {,min }}=-4.50^{\circ} \mathrm{C}, \overline{\mathrm{t}}_{\mathrm{evp}}=-0.59{ }^{\circ} \mathrm{C}\right)$, because the ambient temperature $\left(\mathrm{t}_{11}\right)$ was in the range $5.00 \div-0.50^{\circ} \mathrm{C}$, fig. 2 , tab. 1 . On the other hand, in the mode of operation of the air-source heat pump for the needs of DHW heating, the working conditions were more favourable for the evaporation temperature $\left(\mathrm{t}_{\text {evp,max }}=3.50^{\circ} \mathrm{C}, \mathrm{t}_{\text {evp,min }}=-3.50^{\circ} \mathrm{C}, \overline{\mathrm{t}}_{\mathrm{evp}}=-0.66^{\circ} \mathrm{C}\right)$ given the more favourable parameters of ambient air $\left(\mathrm{t}_{11}=1.00 \div 8.00^{\circ} \mathrm{C}\right)$, and less favourable for the condensing temperature $\left(\mathrm{t}_{\text {con,max }}=\right.$ $56.90^{\circ} \mathrm{C}, \mathrm{t}_{\text {con,min }}=37.00^{\circ} \mathrm{C}, \overline{\mathrm{t}}_{\mathrm{con}}=47.98^{\circ} \mathrm{C}$ ) because it was necessary to heat the water in the tank to a higher temperature $\left(46^{\circ} \mathrm{C}\right)$, fig. 3 , tab. 1 .

Acknowledgments: This research was financially supported by the Ministry of Education, Science and Technological Development of the Republic of Serbia (No. 451-03-68/2020-14200109) and partially conducted within the project "Research and development of new generation machine systems in the function of the technological development of Serbia" funded by the Faculty of Mechanical Engineering in Niš, University of Niš, Serbia.

\section{NOMENCLATURE}

$\begin{array}{ll}\text { COP } & \text { - coefficient of performance } \\ h & - \text { specific enthalpy }(\mathrm{kJ} / \mathrm{kg}) \\ \dot{m} & - \text { mass flow rate }(\mathrm{kg} / \mathrm{s}) \\ p & - \text { pressure }(\mathrm{bar}) \\ Q & - \text { heat transfer rate }(\mathrm{kW}) \\ s & - \text { specific entropy }(\mathrm{kJ} / \mathrm{kgK}) \\ t & - \text { temperature }\left({ }^{\circ} \mathrm{C}\right) \\ T & - \text { absolute temperature }(\mathrm{K}) \\ X & - \text { current variable } \\ \text { Greek symbols } & \\ \Delta & - \text { difference } \\ \mu & - \text { median } \\ \sigma & - \text { standard deviation } \\ \text { Subscripts } & \\ \text { C } & - \text { Carnot } \\ \text { cv } & - \text { control volume }\end{array}$

$\begin{array}{ll}\text { con } & \text { - condensation } \\ \text { DHW } & \text { - domestic hot water } \\ \text { EU } & \text { - end-user } \\ \text { evp } & \text { - evaporation } \\ i & - \text { current measure } \\ \text { lift } & - \text { from condensation to evaporation } \\ \max & - \text { maximal } \\ \min & - \text { minimal } \\ N & - \text { total number of measures } \\ \text { sp } & - \text { set point } \\ \text { tot } & - \text { overall system } \\ \text { UFH } & - \text { underfloor heating } \\ \text { W } & - \text { water } \\ X & - \text { current variable } \\ \text { Superscripts } & \\ - & - \text { arithmetic average }\end{array}$




\section{REFERENCES}

1. Nowak, T., Heat pumps - Integrating technologies to decarbonise heating and cooling, European Copper Institute, 2018.

2. Moran, M., Shapiro, H., Fundamentals of engineering thermodynamics, John Wiley \& Sons Ltd., West Sussex, 2006.

3. Xu, S., Niu, J., Ma, G., Experimental study on R1234yf heat pump at low ambient temperature comparison with other refrigerants, Thermal Science, 23, (2019), 6B, pp. 3877-3886.

4. ***, https://www.iea.org/reports/heat-pumps

5. ***, https://www.ehpa.org/market-data/market-overview/

6. Qui, J., Zhang, H., Sheng, J., Wu, Z., Experimental investigation of $L-41 \mathrm{~b}$ as replacement for R410A in a residential air-source heat pump water heater, Energy and Buildings, 199, (2019), pp. 190-196.

7. Xu, W., et al., Feasibility and performance study on hybrid air source heat pump system for ultra-low energy building in severe cold region of China, Renewable Energy, 146, (2020), pp. 2124-2133.

8. Cakir, U., et al., An experimental exergetic comparison of four different heat pump systems working at same conditions: As air to air, air to water, water to water and water to air, Energy, 58, (2013), pp. 210-219.

9. Yang, Y., et al., Experimental and simulation study of air source heat pump for residential applications in northern China, Energy and Buildings, 224, 110278; https://doi.org/10.1016/j.enbuild.2020.110278, (2020).

10. Amirirad, A., et al., Experimental and simulation studies on air source heat pump water heater for year-round applications in Canada, Energy and Buildings, 165, (2018), pp. 141-149.

11. Nie, J., et al., Experimental evaluation on energy performance of innovative clean air heat pump for indoor environment control in summer and winter seasons, Energy and Buildings, 84, (2014), pp. 641-650.

12. Xiao, B., et al., Comparison and analysis on air-to-air and air-to-water heat pump heating systems, Renewable Energy, 146, (2020), pp. 1888-1896.

13. Cuhla, O., et al., Heat exchanger applications in wastewater source heat pumps for buildings: A key review, Energy and Buildings, 104, (2015), pp. 215-232.

14. Bulatović J., Statistical processing of measurement results (in Serbian), Edvard Kardelj, Niš, 1982.

15. ***, https://www.daikin.rs/sr_rs/products/ERLQ-CV3.table.html

\section{EKSPERIMENTALNO ISTRAŽIVANJE VAZDUH-VODA TOPLOTNE PUMPE U REALNIM USLOVIMA EKSPLOATACIJE ZA RAZLIČITE REŽIME RADA}

U eri permanentne brige o zaštiti životne sredine, potrošnji energije $i$ očuvanju resursa, toplotne pumpe sve više dobijaju na značaju kao tehnologije za smanjenje emisije gasova sa efektom staklene bašte pri očuvanju termičkog komfora u građevinskim objektima. U ovom radu predstavljeni su eksperimentalni rezultati rada vazdušne toplotne pumpe u različitim realnim uslovima eksploatacije, i to: za potrebe grejanja prostora putem niskotemperaturnog podnog grejanja kada je temperatura napojne vode bila zadata na $38^{\circ} \mathrm{C}$, odnosno za potrebe zagrevanja sanitarne tople vode u akumulacionom tanku zapremine 180 litara na temperaturu od $46^{\circ} \mathrm{C}$. Rezultati pokazuju da se u režimu niskotemperaturnog podnog grejanja, efikasnost rada vazdušne toplotne pumpe može podići ukoliko bi se u početnoj fazi rada toplotne pumpe smanjile maksimalna temperatura na kraju procesa kompresije $i$ temperatura kondenzacije. U režimu zagrevanja sanitarne tople vode, efikasnost rada vazdušne toplotne pumpe mogla bi da se podigne ukoliko bi se ograničila maksimalna temperature kondenzacije u završnoj fazi rada toplotne pumpe.

Ključne reči: toplotna pumpa, eksperimentalno istraživanje, grejanje prostora, sanitarna topla voda. 